\title{
Initiative to Create Ideal Citizens in Rural Areas of Turkey: Assembly of Village Institutes
}

\author{
Hasan Gönder (iD \\ PhD Student, Contemporary and Comparative History Program, Doctoral School of History, University of Szeged, Szeged, Hungary \\ $\square$ Corresponding Author: Hasan Gönder, E-mail: hasangonder001@gmail.com
}

\section{ARTICLE INFORMATION}

Received: December 15, 2020

Accepted: February 09, 2021

Volume: 3

Issue: 2

DOI: $10.32996 /$ jhsss.2021.3.2.5

\section{KEYWORDS}

Village Institutes, Criticism meetings, Assembly, Rural areas, Turkey

\section{ABSTRACT}

The subject of the present study is the criticism meetings held regularly in the Village Institutes that were implemented to modernize rural areas of Turkey (1940-1946). Those meetings are entitled as the Assembly of Village Institutes in the present study. The purposes of the criticism meetings were to transform the Institute's students and villagers into modern individuals, eliminate the anti-reform and traditional mentality and spread the idea of a republic in rural areas. This study aims to address the success of those meetings. In the study, first of all, the situation in the villages, the life of the villagers and their mentality before the initiative were explained. Afterwards, Village Institutes initiative as well as, the impressions of the students on the first day they came to the Institute were examined. The criticism meetings held in the Institutes were elaborately assessed, and some events that took place in those meetings were stated in accordance with their sources. Finally, the achievements and success of those criticism meetings were discussed. The present study revealed that the Village Institutes that emerged as a result of the village realities were designed according to the needs of the village. The criticism meetings enabled the transformation of village children, who were docile, submissive, insecure and unaware, into self-confident individuals who knew and sought their rights, and who struggled against injustice. Although this initiative was halted by the change of government in 1946, it enabled to raise about 20 thousand people in a very short time and created a new social status group in the villages.

\section{Introduction}

"If I had my rathers, I would put a course in the curriculum of all schools in the world teaching that people should not exploit the other people ..."

İsmail Hakki Tonguc

The proclamation of the Republic in 1923 legally abolished the Ottoman Empire with its remaining ikta system ${ }^{2}$ in the Sultanate in Turkey. However, the new regime, which struggled for independence after a world war and took over some of the debts of the Ottoman Empire, which it was its successor, faced a wreck. At the same time, the new regime wanted to implement the new reforms without any interruption, however its economic conditions did not make it possible to implement those reforms throughout the country. Therefore, a radical decision was taken to focus on cities representing only $20 \%$ of the population, and reforms were implemented there. In the rural areas, on the other hand, the landlords and imams continued to maintain the old order. The only difference in the newly established republic from the system applied in the Ottomans is that the ikta owners

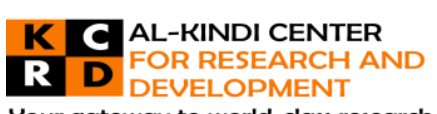

Your gateway to world-class research

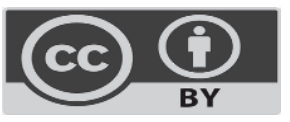

Published by Al-Kindi Center for Research and Development. Copyright (c) the author(s). This open access article is distributed under a Creative Commons Attribution (CC-BY) 4.0 license

\footnotetext{
${ }^{2}$ In the Ottoman Empire, agricultural lands were divided into sections called 'ikta'. These sections were given to iqta owners for cultivation. Ikta owners, on the other hand, paid taxes to the empire and met the needs of a certain number of soldiers in return for cultivating these lands. The difference of this system from feudalism was that the land belonged to the empire, the iqta owners only had the right to cultivate the land and the same person was not allowed to process the same ikta lands continuously (Şen and Türkmenoğlu, 2012: 192-199).
} 
legally owned the lands. Since they participated in and contributed to the struggle for independence, the new regime did not intervene with the landlords and imams who ruled the rural areas, and even tried to reach the rural areas through them.

By 1935, two different types of individuals emerged in the country. On one side, there were urban dwellers who lived in the cities, were conscious, well-educated, aware of their rights, who benefited from all kinds of opportunities of the regime and enjoyed the Republic; on the other side, there were villagers who lived in the rural areas, were unconscious, uneducated, docile, diffident, obedient and unable to make use of the regime in their favor (Tonguç, 2008: 117-120). During the 1930s, the political conjuncture in Turkey, the acts of anti-republican and anti-reformist conservatives -in the incident that took place in Menemen, Izmir in 1930, the supporters of the sultanate martyred a non-commissioned officer named Kubilay (Karaömerlioğlu, 1998: 6869) and the protesters shouting slogans against the regime and reforms at the rally of the Free Republican Party held in Izmir in the same year (Oran, 1988: 179)- showed the seriousness of the situation and in 1935, the Village Institutes initiative emerged as a result of research conducted in rural areas. The most significant practice in this initiative was the criticism meetings which were held on a regular basis. These meetings have been named as the Assembly of Village Institutes in the present study. The meaning of the word "Assembly" according to the Turkish Language Association (TDK) is as follows: (1) A meeting held to speak or discuss a topic; (2) Community of people who came together to discuss or negotiate a topic (Türk Dil Kurumu, n.d.). Since these definitions are suitable for the purpose and function of the criticism meetings held in the Institutes, these meetings were titled as the Assembly of Village Institutes in the present study.

The research question of this study tried to answer how successful the criticism meetings were. These meetings aimed to transform the Institute students and villagers into modern individuals, to eliminate the traditional mentality in rural areas and to spread the idea of republic in rural areas. This study questioned to what extent these meetings achieved their purposes.

In this study, firstly, the situation in the villages before the implementation of this initiative, the life of the villagers and the mentality were given in order to show the change that took place with the Village Institutes. Secondly, the Village Institutes initiative was examined. Thirdly, to show this transformation within the Village Institutes more clearly, two student letters containing the impressions of the students from the first day they arrived to the Institute and a director's memoirs were conveyed. Fourth, the criticism meetings in the Institutes were conveyed in a way to show the progress of the students. Answers were sought to questions such as what the purpose and function of these meetings was, what happened in these meetings, what kind of transformation occurred as a result of the meetings. To present this transformation process, some events that took place in the criticism meetings and reached through the memoirs of the graduates and directors of the Institutes, were given unchanged. Finally, the achievements of these criticism meetings were examined.

As a result of this study, it was revealed that the Village Institutes emerged according to the realities of the village, were designed according to the needs of the village, and with criticism meetings, they turned rural children, who were docile, submissive, diffident and unconscious, into individuals who were self-confident and struggling against injustices. Although this initiative was interrupted by the change of government in 1946, in a very short period of time, approximately 20 thousand people were trained and this created a new social status group within the villages.

Village Institutes has always been one of the most controversial issues in Turkish political history. For this reason, it continues to be discussed even today. Yet, there is not a detailed study in the literature on the criticism meetings held within the Institutes which are the subject of this study. The subject is mentioned briefly only in the memoirs of the graduates and directors of the Institute. Therefore, the present study aims to fill in this gap in the literature.

This research is qualitative in nature. The method of research is historical research. The sources of the research consist of the documents in İsmail Hakkı Tonguç's personal archive and the memoirs of the Institute graduate students and a director. In addition, secondary sources - articles and books - were used to support and complement the study. The resources within the scope of the study were examined according to the document analysis method and the resources found important for the study were determined. Document analysis method is a qualitative research method used to understand, analyze and use data (Bowen, 2009: 27-29). Subsequently, the resources to be used in the study were analyzed using the content analysis method. The content analysis focuses on the question of how a text is understood and what it means for today and analyzes the contents by thematizing the whole text (Şimşek, 2019: 243-244).

İsmail Hakkı Tonguç, who served as the General Director of the First Education between 1935-1946, was the architect of the Village Institutes initiative and the documents in his personal archive were opened to the public just a few years ago, revealing the importance of these documents. In addition, most of the documents that existed in the Ministry of Education (National Education), which were referred by Tonguç in his archive, were destroyed as result of fires, which only increased the importance of the documents examined in the present study. 


\section{The Condition of the Villages, the Life of the Villagers, Attitudes and the Mindset}

In this section, the social, economic and cultural status of the villages are examined and the life of the villagers, the environment in which they grow up and their mentality are analyzed. First, the landlords and madrasahs, which were the most influential actors in the villages, will be examined.

Although Turkey became a republic in 1923, a closed medieval administration and economy based on the traditional overlord regime have been maintained in rural areas, which covered approximately 80 percent of the society until 1950 (Tonguç, 1976:6). There were two main actors who had the authority in rural areas. On one hand, there was army and on the other, there were landlords and religious leaders. Especially in the first years of the Republic, it seemed that balance and reconciliation have been achieved between the conservatives and reformers within the regime. Conservatives supported the regime and reforms in the city, provided that the regime did not contradict their interests within the rural areas. Until 1935, the regime tried to reach the rural areas through rural notables. According to Sabahattin Eyüboğlu (1979), one of the intellectuals of the period, who was also working as an Institute teacher, another reason why the regime left rural areas to landlords and imams was the attitude of intellectuals and people living in the cities towards the villagers and the money spent for them. Eyüboğlu explains this situation as follows: "Even in the mouths of our most vigilant ones, the name of the money and labor spent for the villagers, is sacrifice, as if the state is not their state as much as it is ours" (p. 40-41).

It is also necessary to examine the relationship between the villagers and the empire that the young republic is successor to, in order to understand why the villagers were dependant on the landlords and villagers regarded them as the authority. For the empire, the villagers were seen only as potential soldiers and taxpayers, and they were forced to seek help from the agha, bey and cult leaders in order to do their jobs in all matters. The villagers were made unable to make a simple request from the administration, let alone to join the administration (Aydın, 2018: 17). The landlords had the right to expand their authority in the rural areas of the country in return for an agreement with the regime.

Religious leaders, another actor, established their influence in rural areas, again based on the days of the empire. Tonguç (2020) explains the influence of madrasahs in rural areas as follows:

Since the madrasah is an institution that has influenced the development of our cultural life in past periods and can be considered to have accomplished its mission in terms of realizing religious education, its traces can be found everywhere in the city or in the village, where the groups of people who accepted Islam accumulated. Tens of thousands of villages that have not yet had a teacher or tutor are still ${ }^{3}$ in the hands of imams and preachers trained in madrasahs (p. 103). Because those who were educated in this institution were also teaching in religious primary schools that were opened next to them, like branches of mosques; children who attended these schools were taught parts of the Qur'an, which was written in a language they did not understand (Arabic), by which these instructors trained children who would become devoted to the religion of Islam and obident to the state as it was their duty, and act in accordance with religious orders, not with their own ideas. As a result of these, the instructors attempted to explain even the simplest events about nature with the influence of jinn, fairies, winged and secret creatures, and by instilling these opinions on the children and people they were educating, they began to educate groups of ignorant and compliant (harmonious), raising numbers of people of their kind (p.105-106). The reason why imams educated in madrasahs were influential in villages was that they were also from the same village. The imams, where they were born and raised in the places where they served, and where their graves were buried as well, had absolute authority in the villages. Students who were beaten with wet feet in the birch were taken home by friends, and their families were resentful of their own children instead of resenting the imam (p. 174).

After examining the active actors in rural areas and explaining the reasons for their influence, the conditions of the village will be examined in this section. Mahmut Makal (2019), a graduate of Village Institutes, conveyed his observations in his book entitled Our Village, after he returned to his village:

Most of the villagers did not have shoes. They wore pattens. Very few people wore socks. In winters, they burned not wood, not coal, but dung, if they could find it (p. 11). Burning the dung brought along health problems because it attracted mosquitoes and rowan from the smell of dung. According to Makal, this was one of the reasons why diseases were common in the villages and he thought that the death rates of the villagers could be reduced partially by solving the heating problem. However, he stated that freezing children were commonly seen in the villages, as most villagers couldn't even find dung to burn (p. 15). Another observation Makal made was that some villagers did not have animals to plow the land and that people replaced animals and plowed the soil (p. 28).

\footnotetext{
${ }^{3}$ Tonguç's statement points to the year 1939 when the document was written.
} 
Regarding health, Makal visited villages with the help of his healthcare worker friend Nuri Altınbaş, measured the perception of the villagers towards the notions of doctor and hospital, and recorded the birth-death rates: "Most of the newborns and children died due to the cold, and the villagers believed that this was God's will. In fact, many people murmured behind the doctors as 'God is the one who gives and the one who takes. As if the doctors could go against the wisdom of God.'" (p. 13-14). Mahmut Makal's village had 130 houses, which meant, 130 families. Makal reported that only in February, 34 children died. His healthcare worker friend was taking care of 13 villages and the number of children of those villages he wrote on the death sheet for February was 120 (p. 14-15). He explained his observations in more detail about the 13 houses he visited during this trip:

"'In a village with 13 houses, 29 births and 13 deaths occurred in 4 years. So, the death rate is $45 \%$. However, the more children there were in the house, the more they slept sick as if it was winter. I wanted to know the cause of children's illness. First, they claimed that it was the thirst and the dirty water. Apparently, they were bringing the water from the village of Nebili, which was 20 minutes away. There were no wells, no fountains, or a flowing drop of water in their village' (p.46). Makal claimed that the reason deaths were so high was the lack of childcare knowledge in the villages. Makal concluded that nine out of ten children who died in the summer suffered from diarrhea. When a child suffers from diarrhea, the villager would give up on him/her and regarded him/her as dead. According to Makal, the main cause of deaths was poverty (p. 78-9)."

As Baha Mutlu Aydın (2018), a graduate of the Village Institute, reported: the villagers preferred to pray to the shrine and tie a rope to a bush for their illnesses (p. 17). If the disease was in the inner limbs, they would pour lead, have people made amulets. They would have people read the Quran and make sacrifices, so that the disease could pass quickly (Tonguç, 2020: 74).

Finally, in this section, the document explaining the obvious qualifications and needs of the villagers and the village children in Tonguç's personal archive is cited:

First, the villagers were tough and conservative in nature. While the villagers maintained their entire life within nature and natural events, their culture and knowledge of nature related affairs were quite high. In terms of social and cultural life, the villagers have been loyal to the way of the old period and have had a hard time keeping up with modern life. The life of the rural child was limited. While the demand for old continued in the villages, the life of the village children would last in the narrow neighborhoods surrounded by them. As soon as they would leave that neighborhood, their self-confidence would be decreased and they would begin to draw a protective image around themselves. The families and neighborhoods of the rural children, who would start working hard from a very young age, educated them in the first place. Rural children struggled with all kinds of incidents and effects that harmed them and tried to resist those incidents by themselves. At that time, village schools were not sufficient according to the conditions of the villages. Village schools were not designed in accordance with the needs and characteristics of the villages. In this respect, the school could not provide the education and skills that the rural children needed. Schools that should provide the village children with the education they need and equipped with that competence were required (Tonguç, ca.1936: 3).

\section{The Initiative of Village Institutes}

The encyclopedia called Lexicon der Pedagogik, published in Switzerland in the broadest sense, has described what kind of a project the Village Institutes were. As referred by the Village Institute graduate Baha Mutlu Aydın in his work entitled Village Institutes and Community Development (see Köy Enstitüleri ve Toplum Kalkınmasl), in above-mentioned encyclopedia's article titled "Eradicate ignorance", it is stated as follows: "The Village Institutes in Turkey tried to understand and solve the problems that concerned the villager masses by seizing them, suggested solutions to resolve them, and trained teachers who had the skills to improve the daily work and life of the villagers in material and moral terms." (Aydin, 2018: 2).

What was desired to be achieved with the Village Institutes is clearly presented in the document named First Education Law from Tonguç's personal archive: raising a generation that will defend the revolution. The aim of the Turkish Revolution is, on the one hand, to make the young and intellectual group in Anatolia adopt its ideal, on the other hand, it is to raise its own generation loyal to this regime (Tonguç, 1934: 1-3).

Sabahattin Eyüboğlu has made the best description of the Village Institutes. According to Eyüboğlu, Village Institutes were a matter of getting the majority out of the dark (Eyüboğlu, 1979: 52).

According to the census data of 1927, it was understood that one out of every 12 people living in the country could read and write (in Arabic letters). According to the census made in 1935 after the alphabet revolution, this rate increased to one in every seven people (Köy Enstitüleri ve Çağdaş Eğitim Vakfı, 2003: 76). The population of the country was scattered across 40,000 villages and more than 470 cities and towns. $80 \%$ of this population resided in villages, the rest in cities and towns. According to the data of 1935, there were approximately 1.2 million children of compulsory education age who did not go to school. While 
this number was more than one million for villages, it was around 170 thousand for cities. One of the most important reasons for the high number of villages was that the rural areas were dispersed and the population of the villages in these areas varied between 30 and 1200, and the population of 32 thousand of the existing forty thousand villages was below 400 (Tonguç, ca 1936: 2).

\subsection{The Program of Village Institutes}

The work titled Village Institutes I-II, published by the Village Institutes and the Contemporary Education Foundation (see Köy Enstitüleri ve Çağdaş Eğitim Vakfı) in 2003, is one of the important sources prepared to inform the public in between 1941 and 1944 in terms of the developments and activities of the Institutes. Village Institutes and the Contemporary Education Foundation brought these two works together, prepared them for publication and presented them to the reader. They provided detailed information about the programs of the Institutes, the education period of the Institutes was five years. During this period, 114 weeks included culture, science and teaching knowledge lessons; 58 weeks agriculture lessons and studies; 58 weeks were spared to technical lessons and studies and 30 weeks to holidays. They worked 44 hours a week. Half of the students in all classes were devoted to culture lessons, half of the remaining students of the same classes to agriculture and half to technical lessons and studies; work schedules were determined on half-day, all-day and one-week basis. In case of extraordinary and important works such as buildings, roads, bridges, water arc openings that needed to be done immediately, necessary sowing, sickle, threshing that needed to be completed within a certain period, adequate number of students and teachers would be employed all day, week or a few weeks. Lessons or works that the student participating in such studies could not continue within that period would be compensated by taking the necessary time in the next study plans (p. 118-121). Although this was expressed optimistically by the directors of the Village Institutes, it was often not possible to realize this compensation. The reason for this was that the Institute's programs were prepared according to certain systematic and agricultural and technical studies. Furthermore, the Institutes have been able to finance themselves thanks to their agricultural and technical studies.

In addition to the teaching profession, the students of Village Institutes were taught agricultural work to the extent that they could guide villagers. In addition, starting from the second grade, children were taught a profession needed in the village. These professions were blacksmithing, carpentry, building for men; for girls, they were sewing-knitting, netting and weaving (Tonguç, ca.1941a: 13-14). Students would be able to do these professions with success in business life, to apply them according to the characteristics and needs of the environment they would become teachers, and to benefit the villagers in this regard. Also, village health officer and mobile village midwife were also raised in the Institutes. These duties assigned to the Village Institutes were determined considering the vital needs of the village and applied after the necessary measures have been taken (Köy Enstitüleri ve Çağdaş Eğitim Vakfı, 2003: 119).

\section{The Way of Arrival of Students and Teachers to the Institute and Their Situations}

In this section, the way students and educators arrived to the Institute and what they encountered when they came to the Institute are given. The main purpose here is to show the situation of the Institutes when they were established and the perspective of the students and the educator towards the Institutes.

Aksu Village Institute Director Talat Ersoy explains the various difficulties they encountered in the early days of the Institute as follows:

"The educators had not yet been given dresses and shoes. It seemed that there was almost nothing left on them, as they had come wearing the oldest ones, as they did when enlisted. I was seeing them, I was noticing them, but I could not find a solution since our money transfer had not yet arrived at the Antalya Accounting Directorate. One day, four educators stood before me. One of them said:

- $\quad$ "Sir, the earth burns my feet. My soles are swollen. You know how bad this situation is."

The other pulled the end of his underwear from the torn place of his trousers and said:

"I can't go to the coffee shop to buy tobacco."

Others complained that they were running out of pocket money and had no clothes and shoes. I ordered them to have their dress and shoes measured. In order to handle the situation, I asked them if they came for them or not. They said that noone had come yet. I told them that I did not like the fabric of the made ones, and that their shoes and clothes would be sewn as soon as possible. Until then, I offered that they'd wear my clothes and shoes. They said that they didn't want that option and it would be a shame. I told them that there wouldn't be any shame and we were all for one there." (Köy Enstitüleri ve Çağdaş Eğitim Vakfı, 2003: 149-151).

Kastamonu Göl Village Institute 3/D class student Mustafa Gurbetçi, whose school number was 358 and who was 15 years old, wrote about his arrival at the Institute and his experiences. When he wrote this document, it was his third year at the Institute and stated in his letter that he regretted what he did. This document was obtained from Tonguç's personal archive. In this document, it is said as follows: 
He set off from his village on March 27, 1939 and arrived at the Institute one day later. After enrolling at the Institute, he was stunned by the scenery he saw when he got down: two students got under a tree too big to be carried even by a pair of oxen and they were carrying it. The other two students took four cans of water on a stick on their shoulders, while they were going, their feet entered one after another under the load. Mustafa couldn't even eat a bite for lunch. Later, the students went to reading, he also participated but did not study. When the bedding drum went off, they showed his bed. He couldn't sleep that night and wanted to go back to his village. When he got up in the morning, the dining hall was being built and he was given the task of carrying mortar. He says his hands were in a lot of pain after carrying 8-10 cars of mortar. After spending 2-3 days like this, the first thing he did was to write a letter to his village. He begged his father to take him, because he couldn't get used to it. Later, while working in an agricultural drill, he caught cold. He was giving the director a headache every day after he was cured, as he wanted to leave there definitely. About 10 days later his father came. After the director talked with his father, they convinced Mustafa together (Tonguç, ca. 1941b: 1-2).

In another document written on December 22, 1941, İsmail Sönmez, a student of 3/C class at Göl Village Institute, from the village of Dümelisaray in Çankırı, whose school number was 319 and who was 20 years old, explained how he came to the Institute as follows:

He mentioned that the villagers were doing business blindfoldedly, that they were inattentive farmers, that his deceased father, like them, cultivated and that they could barely maintain their lives, and their financial situation was bad. He explained that since his village was big, there was a school in there and said that he lost his father right when he finished school, had no other brothers or sisters and stayed with his elderly mother, that his luck did not help him even though he applied to a few places and therefore lost 2 years. Afterwards, he was accepted to Kastamonu Göl Village Institute and came to the Institute on April 4, 1940. After registration, he was given clean clothes and sent to the bathhouse. He went to the cafeteria after the bath and while he was eating, he heard a noise and someone said that the radio was turned on, and offered to listen to it. Ismail emphasized that he heard the name of the radio for the first time. Then he went to the dormitory and told that he slept on the place shown for him and woke up with a bell after a good sleep. After washing his hands and face, here he brushed his teeth for the first time in his life, gathered with the second bell and had a quarter-hour gymnastics lesson, he had breakfast with the third bell, the number of students decreased when he gathered again with the fourth bell. When he asked his friend Bayram where the missing students were going, he replied that they went to the class. When he asked Bayram where he and his group were going, Bayram replied that they were going to work. Later, he said that they built these new buildings they saw, that they cultivated the vegetable garden, and that the guards wandering around the bed at night and those working in the cafeteria and so on were all students as well. İsmail was very surprised by this situation, he thought it would be like other teachers' schools because he came to the teacher's school. But three years later, he said that he understood what was meant to be done. According to him, the young republic opened these schools in order to make a revolution on them, gathered the children of the villagers, who knew the diseases of the villagers, and gave many opportunities to the children of the villagers to learn about the treatment of their illnesses (Tonguç, 1941: 24-25).

\section{The Assembly of Village Institutes}

There was a principle applied in every Institute. A meeting was held at regular intervals -once a week in some Institutes, and once every two weeks in some- with the participation of everyone from the director to the cookery. In these meetings, weekly events, successes and failures were revealed, and openly criticisms were made (Arman, 2016: 304). The most important feature of these meetings was that everyone who attended had an equal say and that titles such as director, assistant director or teacher did not matter. Students were free to make any criticism. Pakize Türkoğlu stated that criticisms were sometimes directed to directors and teachers, and that they took this with great seriousness and responded to questions and criticisms (Türkoğlu, 2019: 368). However, criticisms without evidence, witnesses and personal grudges were not tolerated; the head of the education 4 would get them under control. Sometimes the discussions would get intense and sometimes they would get quieter. Those who did not tolerate criticism were warned and those who criticized rightly were thanked. Students were guided accordingly. Since these meetings were held in most Institutes on Saturdays, some graduates of the Institute named these meetings as Saturday Meetings in the works they have written. However, since these meetings were held every two weeks in some Institutes and they were held under the title of village talks on Mondays at Akpınar Village Institute (Village Institutes and Contemporary Education Foundation, 2003: 167), it is understood that it was not appropriate to call these meetings as Saturday Meetings. On the other

\footnotetext{
${ }^{4}$ The head of education is the person who is responsible for all the educational affairs in the Institute, who also teaches his own branch courses, provides discipline in the Institute, manages the Village Institutes Council and ensures that all works in the Institute are carried out regularly (Yıldız and Akandere, 2017: 283).
} 
hand, it has been realized that the word assembly was suitable for the function of these meetings, therefore these meetings are named as the Assembly of Institutes in this study.

The form and method of these meetings were revealed by Ismail Hakkı Tonguç, the architect of the Village Institutes. During the foundation years of the Institutes, Tonguç would receive letters of complaint from teachers, students or other employees or villagers. When he went to the Institute, he would say that if it would concern teachers, he'd gather only teachers, and if it would concern students, he'd only gather them and say that the writer of the unsigned letter should clearly express his views, discuss them together, and that there would be no harm to him (Türkoğlu, 2019: 369). He encouraged all the staff of the Institute, especially the students, and gave advice on the organization of these meetings.

Surely, this culture of criticism and democracy could easily be observed in Tonguç's character. In his reply to the disrespectful and exceeding letter sent by Emin Soysal, who worked under him and was the Director of the Kızılçullu Institute, in a letter dated 8 November 1938, he said, "You used plenty of words that have been said inconsequentially. But since these are arrows that can finally hit me, I can pass them without any sadness. Because I am in a position to think that I gave it with my own hand when I should not have the arrow shot" (Tonguç, 1976: 27), showing how much he attaches importance to criticism and democracy.

These meetings were held at every Institute with the encouragement of Tonguç since the Institutes were established. It is possible to find traces of these meetings in the letter Tonguç wrote to all Institute directors on December 4, 1944. This letter contained the instructions given to the Institute directors. These instructions were:

'It is forbidden to beat or insult students. Teachers are required to eat their meals with the students. All teachers and students come together and talk at least every 15 days. And things are carried out in accordance with the decisions made in these conversations, taking into account the possibilities, the directives given by the attorneyship. Entertainment is organized at the Institutes at least every 15 days. Every day, children are made to have free reading hour, regardless of the conditions. (Tonguç, 1976: 90-91).

In these meetings, not only criticism or self-criticism was made, but also appreciation and thanks were reported, achievements were praised, and those required were rewarded. To give an example, when a cluster working in the construction works realized that the weather was going to rain, they worked as they did during the day, and continued until the morning at night, closing the roof before it rained and saved the Institute from great damage. These students and teachers were thanked at the meetings (Türkoğlu, 2019: 371).

The aim with the assemblies of the Institutes was to help students gain the ability of self-expression, to help them get used to talk by having enough exercises in the lessons, to improve their vocabulary with free readings, to eliminate this shyness and detention by giving speeches in front of the public by reciting poetry, giving a role in games prepared at weekly entertainment. However, the main method and environment for improving this issue was to make good use of the criticism meetings. The students should have gotten used to speaking in these meetings and should have been able to express themselves (Baykurt, 2019: 91). If this could not be achieved, these trained staff would have remained unconscious, simple, foldblindedly obedient to every order given, as in the past, they would have got used to the backward life of the village and ended their lives according to their destiny. There would have been no change in the villages, the villages would have continued to remain in the medieval darkness (Tonguç, 2020: 539). Tonguç took various measures to prevent this and implemented the Village Institutes initiative to awaken the villagers, save them from the darkness of the Middle Ages and revitalize the rural areas.

\subsection{Some Events in the Assembly of the Village Institutes}

In this section, some events that took place in the assembly of the Institutes were conveyed without any changes, using the memories of Village Institutes graduate students and Beşikdüzü Village Institute Director Hürrem Arman. On this occasion, by focusing on the details of some of the events spoken in the Assembly of the Village Institutes, it will be examined to what extent the social transformation aimed at these meetings has progressed.

\subsubsection{The Food Incident}

Fakir Baykurt brought the injustice he witnessed in the cafeteria when he was a first-year student at Gönen Village Institute as follows:

'... Large classes were lined up first. Food delivery would have started from them. When it'd come to small classes, water was added to the lunch... Fifth grade vice president brother Ahmet also was aware of this situation.'

Thereupon, the fifth-grade student Ahmet from Gebrem was promised to confirm the incident: 
'The friend with the yellow jacket was right. It happened on my watch. The chief cook added water to the meal. I said, be careful, don't add water when it comes to the younger students, sir.' Then, the head of education asked the other side of the event to the chief cook: "Is this true?"

Chief Cook Süleyman: "Sir, the number of students has been increasing recently, I cannot manage the amount with my hand." The head of education warned the cook as follows: 'The food comes out of the warehouse exactly according to the number of people. Be more careful from now on'" (Baykurt, 2019: 29-31).

\subsubsection{The Bread Incident}

During the war and famine years when bread was rationed, the flour given to the Institutes barely met the need. For this reason, bread was given in numbers and measures. It was decided in the previous meeting that the number of bread determined by the head of the Institute should be delivered to the head of the dining hall and that no one could ask for bread from the bakery, which was located in most Institutes. Aksu Village Institute student Pakize Türkoğlu narrated the meeting of that day as follows:

Bakery chef Şevket began to speak and stated that the decision taken at the previous meeting was not followed. He was a student of two years younger than us and said:

'Friends, we made a decision here, but you came and ask for bread from me. It saddens me not to give bread to anyone who asks for it. If I give, I will be unfair; there is a decision. A teacher came yesterday and I could not give him any bread either. "I'm truly sorry".

The students were observing the environment with curious eyes after the bakery chef's words, who was this teacher? The carpenter teacher, Mustafa Rende, jumped from his place and without bending over said:

'Everyone, that greedy teacher is me,". He continued, 'You know I'm a teacher who eats a lot. Also, I had a guest, that's why I wanted some bread. Your friend didn't give but he did well. I shouldn't have made such a request. Thanks to this Institute, I left many habits behind. I am also thankful to Şevket. I like him, I was never offended."

Şevket started speaking again and he said:

'Friends, I also am thankful to our teacher, but the problem is not solved,". He turned to the director and managers and offered a solution: 'We talked to the head of education. If we find some corn and grind it, we will add it to the flour we have and we will have no bread troubles.'

The deputy director of money affairs started speaking and thanked the teacher and the bakery chef and said that students and teachers who are not fed should apply to the head of the cafeteria, not the bakery, and that more bread will be given to the cafeteria after today (Türkoğlu, 2019: 369-370).

\subsubsection{The Cape Incident in the Dormitory}

Fakir Baykurt, a student at Gönen Village Institute, described the event he witnessed in the Institute's assembly as follows: It is very frosty in Gönen. We could not cover the bedrooms because the tiles were not enough and some places remained open. Almost everyone was coughing because of the cold. As a solution to this problem, it was decided to give the students a cape. But they started from the upper classes to distribute the capes. Students from subclasses were waiting for their turn. A third-grade friend named Kemal asked why the sewing house did not sew enough cloak and capes by working with two shifts even though there was enough fabric in the warehouse, and asked which assistant or the manager was responsible for this and looked for an answer. The director got up and answered, he said that they did not think of running the sewing house in two shifts as day and night, that this would have been a fault, that the criticism was justified and thanked the friend (Baykurt, 2019: 93-94).

\subsubsection{The Pickax Incident}

Abdullah Özkucur, a student of Çifteler Village Institute, described an event that took place in the Assembly of the Institute in his book The Epic of Village Institutes (see Köy Enstitüleri Destanı), published in 1985, as follows:

One of the students: 'Guys, an hour ago I saw two pickaxes next to the water tank. I asked my friend who was responsible for the tools watch. Don't you give these to the employees by numbers every morning? Do you have any information regarding the lack of these two pickaxes right now?' he asked.

One of the tool guards, Mustafa Buğday took two steps forward and started speaking and gave the following answer:

'My friend, I just went to workplaces. I saw the pickaxes you mentioned by chance. I took and brought them. I put them in the tool store. I would thank you for your warning, but I won't. Because I didn't like your attitude. If you saw those pickaxes there, why didn't you bring them and hand them over to me? "

The critic suddenly shouted:

'I don't care! I did not take them, so, I don't have to bring and deliver them to you either."

Mustafa Buğday replied: 
'How can you not care? I cannot see sincerity in the criticism of a person who said this. Are you not a student of this Institute? Is this Institute not your home? Everything that exists in this Institute from needle to the thread is yours as well, isn't it? How can you pass through the pickaxes you see? Didn't your heart bleed out doing that? We should not abuse even a nail of our nation." (Özçukur, 1985: 75-76).

\subsubsection{The Sewing Incident}

Pakize Türkoğlu described the incident that happened to her at the Institute's Assembly when she was the head of the sewing workshop at Aksu Village Institute:

'... In addition to the sewing work at the Institute, we were also doing the clothes repair of all students. Cavit Oral Binbaşıoglu from our class started speaking in a criticism meeting. He said that he, like other students, put the coveralls to be repaired in front of the sewing workshop, but that although all the clothes were repaired, his overalls were still there, that the girls sewed the clothes of their favorite friends, that those clothes that belonged to poor people like him were not handled, and that it was not friendly and fair at all. Cavit Oral was a student with principles. That is why everybody looked at me and the sewing teacher upon his criticism. The director of the Institute was very meticulous and sensitive on these matters. As the president, I also had a great responsibility in this arrangement. I took the floor and said that our friend Cavit was wrong, that his coveralls were not sewn due to the intensity on the first day, but that I personally sewed and put it back on the second day and that it had been standing there for many days. Cavit Oral apologized' (Türkoğlu, 2019: 370-371).

\subsubsection{The Incident of Short Pants}

Hürrem Arman, director of the Beşikdüzü Village Institute, described the short pants incident discussed at the Institute's Assembly as follows:

One day we raised the issue of short pants. The climate was very hot and humid. Workwear with long trousers made the children uncomfortable. If they would have worn short trousers, they would have been much more comfortable and instead of one long trousers, two short trousers could have been produced for everyone. This issue had been highly controversial.

Many of the students said: "We would've been ashamed, our legs would've been look ugly, we are not used to this, our girlfriends also would've mocked us, how could've we wear short pants while they'd be wearing long pants?" After all, this was a matter of habit and there was nothing to be ashamed of. It was also suitable for the environment and would have provided comfort for the students.

A few of the female students also took the floor. One of them said: 'Why would we laugh to that? You'd be comfortable. At first, maybe we'd find it strange but then, we'd get used to it. I don't see anything funny about our boyfriends wearing short pants.'

A male student who opposed this issue said: 'Will all our teachers wear short pants too?' He put forward the idea that if they'd wear it, students would wear them as well. A positive side appeared.

Taking the floor, I said: 'I will wear it, I think our teachers will agree too, they can also express their opinions. Let's just not interfere with the master teachers, that wouldn't be right."

A 60-year-old Aziz Aga, a motor captain, a fisherman, an agricultural master teacher, would not suit this with his long beard. The teachers also shared their opinions and the decision was made with applause (Arman, 2016: 304305).

\subsubsection{The Milk Incident}

Hürrem Arman, director of the Beşikdüzü Village Institute, described the milk issue discussed in the Institute's Assembly as follows:

A child in one of the sessions said: 'Our cooperative has five cows, 25 litres of milk is received a day, what happens to this milk? We do not drink milk at all, let the chairman of the cooperative explain this.'

Before the chairman of the cooperative, another child interfered as: 'The milk always goes to the teachers' house'. Another said: 'His assistants go to the director's house every day and carry three litres of milk with them.'

The head of the cooperative took the floor and said: 'Thinking that the milk will not be enough for all students, he said that it was sold to teachers for money and gave the accounts of how many litres of milk went to everyone's house and the income earned. These sales were carried out in order to pay off the purchase price of the cows.'

One student said: 'The cooperative is right in this issue. If 25 litres of milk is divided into 500 people, not even a sip falls.'

Another suggested: 'It could be collected, given once in every few days.'

Someone else responded as follows: 'Milk cannot be kept for long, it'd be spoiled, this offer cannot be implemented.' 
Another child found a real way out and said: 'Each day's milk could be given to 100 people with a quarter-litre calculation. The next day the other 100 people, then the others... If this would have happened, everybody could have drunk milk every five days.'

The decision was made accordingly. The children were quite right. Teachers could find milk from outside, even if it was a little more expensive (Arman, 2016: 305-306).

\section{The Effects of the Village Institutes Assembly on Students}

In this section, the contribution of the Village Institutes Assembly on the students and villagers will be examined. With these meetings, it was aimed to transform the villagers from an indistinct, shy, submissive society into a society that could defend their rights, consists of self-confident people, who also could struggle with injustice. Surely, in the first stage, the transition would have started with the students and this change would have been transferred to the villagers when the students would have been graduated and would have gone to work as teachers in their villages. For this reason, the benefits and effects of these meetings should be evaluated from two aspects: first, how successful the meetings were among the students of village Institutes; the other is its applicability and success among the villagers.

Firstly, as can be seen from the examples given in the previous sections, the criticism meetings were successfully implemented among the village Institute students and they turned into people with self-confidence, who were aware of their rights, who were able to think and question the issues. The students could fight against the injustices they encountered, express their problems and it was ensured that the wrong practices were changed. As seen in the food and cape examples, Fakir Baykurt, a first year student, and Kemal, a third year student, were able to criticize the incident and demand the correction of the injustice. Students have also learned to apply the rules, regardless of any rank or title. As seen in the bread incident and the milk incident, when a top ranking person would have been requested or done something unfair and illegal, the students would apply the rules regardless of their title and demand the correction of the injustice. Finally, in the case of short trousers, the students having such heated discussions on a topic, negotiating with the management, and agreeing to wear them on the condition that the teachers also would've wear those short pants clearly presented this paradigm shift occurred within the students. These discussions and criticisms, which were open in all aspects, had positive and constructive effects in all applications. It is seen how the Institutes defended the rights of the "awakened villagers", as referred by Tonguç, and acted accordingly.

Turkey made the transition to a multi-party system in 1946. With the election held in the same year, the Democrat Party (DP) entered the assembly as the opposition party. This situation changed the equilibriums within the Republican People's Party (CHP), which was the only party since 1923, and the conservatives within the party ruled out reform supporters and established a new government the same year. The conservatives within the CHP and the DP were disturbed by the activities of the Village Institutes because they contradicted their interests and both parties opened various investigations in the assembly regarding this initiative. The following question posed in one of the undercover investigations reveals this transition in the Institute's students, although they interpret this culture as anarchy:

'Those from the Institutes were challenging the governors and district governors, complaining to the president. Isn't this anarchy?' (Başaran, 2019: 159).

The thing that conservatives regarded as anarchy was to defend the rights of graduates of the Institute and fight for them. However, the conflict of the Institute's activities with the interests of the conservatives pushed them to move in this direction. Because it was agreed that the teachers of the Village Institutes would go to the villages as spokesman of the new Turkey and the plan was the modernization of rural areas with the help of them. This order within the rural areas of Ottoman Empire would have been disrupted with the Institutes. However, this was prevented by the change of government in 1946. Village Institute teachers, the first intellectuals trained in rural areas of the country, formed a new social status group as Karpat (2019) said and fought against landlords and imams (p. 196-197). In addition, as Karpat defined it, this new generation of intellectuals were seeking a new philosophy of life that would allow Turkish society to preserve its core values, to advance and adapt to contemporary conditions. The aim of these intellectuals was not different from the aim pursued by the old generation intellectuals, but their methods and mentalities were different. Liberal thought, the idea of equally respecting and accepting other values, found its expression in the new generation of intellectuals. Also, these intellectuals were socially conscious and realistic. On the other hand, the older generations of intellectuals were inclined to be conservative, far from the public, and continued to live in their own romantic world (p. 217-218). But, this new generation of intellectuals failed to enlarge and spread this social status group they formed to rural areas.

The purpose of these criticism meetings was reached among the students of the Village Institute. The same couldn't have been said for the villagers. In 1946, this attempt was undermined by the removal of Tonguç, Yücel and important directors and teachers in the Institutes. Institutes that created thousands of children from scratch in a short period of six years, disappeared 
before they could have reached the villages. In the period after 1946, the activities of the graduates of the Institute were closely followed and their work and activities were prevented. In order not to be accused of being communists, most Institute graduates could not carry out the work they wanted. Some of the outstanding graduates continued to do their research in the villages they went to, and even tried to apply the criticism meetings. Makal tried to make them a tradition for everyone to listen and share what they thought, by reading a book, magazine or newspaper in the village room on days when he did not teach in winter, and sometimes on Sundays (Makal, 2019: 128). Of course, these meetings were not as comprehensive as the ones that took place in the Institutes.

The reason why the Village Institutes are still on the agenda of the country and discussed is that what has been realized and achieved with this project has not yet been succeeded. Unfortunately, the self-confidence, awareness and criticism culture skills gained in the Institute students through the criticism meetings have not yet been widely achieved in the country today.

\section{Conclusion}

In this study, criticism meetings held regularly in Village Institutes and which we call Village Institutes Assembly were examined by using İsmail Hakkı Tonguç's personal archive documents, the memoirs of graduates and director of the Institute and other supporting sources. In the previous section, it has been stated that these meetings were successfully implemented by the students of the Institute and that these students were recreated with the Institutes, but this initiative was terminated with the government change in 1946 and couldn't have been implemented and spread among the villagers.

At the beginning of this study, we tried to reveal the situation of the villages, the life of the villagers and their mentality in the 1930 s in order to clearly show the transformation that the students of the Institute underwent. Moreover, we wanted to show this transition more clearly by revealing the mentality of the students on the day they arrived to the Institutes and their first impressions regarding the Institutes.

As a result of this study, it can be said that the Village Institutes are an initiative beyond its age and that it was implemented successfully until 1946. With this initiative, 26,674 people were educated in Village Institutes. 16,400 were teachers, 1,599 were healthcare professionals, and 8,675 were educators (Kapluhan, 2012: 184-185). These people who have been trained have turned into individuals who were conscious, aware of their rights and defended their rights, self-confident, sensitive, critical and open to criticism and devoted to the values and virtues of the Republic. The role of the Village Institutes Assembly in the realization of this transformation is clear. In this respect, these criticism meetings were vital for the Village Institutes initiative to achieve its goals. Otherwise, instead of revitalizing and modernizing the villages they lived and worked, the educated teachers would have kept up with the conditions of the place they arrived to and continued to leave the villages in the dark by resigning themselves to the landlord or imam. The criticism meetings aimed to prevent this. In addition, the Institute teachers and educators became the country's first villager intellectuals by creating a new social status group.

The fact that the criticism meetings of the Institutes, which are the subject of the current study, were not examined in detail in previous studies -the events that took place at these meetings and made marks are only mentioned briefly in the memoirs of students and directors- made it difficult to find sources on the subject. Since the number of students in the Institutes where approximately 26 thousand students received education were high and it would be difficult to review the work of all students, this study is limited to the works and memories of a certain number of graduates who have been active and have come into prominence within the society with the books they have written and various studies they carried out after being graduated. Finally, in the future studies, a more comprehensive study can be made on the subject by making use of other studies and memoirs written by the graduates of the Institute that were not used in this study. In addition, it can be examined whether these meetings were maintained in the education system of Turkey after the period of Village Institutes or a similar practice exists in today's education system.

Funding: This research received no external funding.

Acknowledgments: I would like to dedicate this work to my nephew, Miran Toprak Balin. Even though he is eight months old and thousands of miles away, he has kept me motivated with his smiles and laughter during our video calls.

Conflicts of Interest: "The author declares no conflict of interest."

\section{References}

[1] Arman, H. (2016). Piramidin Tabanı I-II. İzmir: Yeni Kuşak Köy Enstitülüler Derneği Yayınları.

[2] Aydın, B. M. (2018). Köy enstitüleri ve toplum kalkınması. Ankara: Anı Yayıncılık.

[3] Başaran, M. (2019). Büyük Aydınlanmacı Öğretmenim Hasan Ali Yücel. İstanbul: Türkiye İş Bankası Kültür Yayınları.

[4] Baykurt, F. (2019). Unutulmaz Köy Enstitüleri. İstanbul: Literatür Yayınları.

[5] Bowen, G. A. (2009). Document analysis as a qualitative research method. Qualitative Research Journal, 9(2), 27-40.

[6] Eyüboğlu, S. (1979). Köy Enstitüleri Üzerine. İstanbul: Cem Yayınevi. 
[7] Kapluhan, E. (2012). Atatürk Dönemi Eğitim Seferberliği ve Köy Enstitüleri. Marmara Coğrafya Dergisi(26), 172-194.

[8] Karaömerlioğlu, M. A. (1998). The People's Houses and the Cult of the Peasant in Turkey. Middle Eastern Studies, 34(4), 67-91.

[9] Karpat, K. H. (2019). Türk Demokrasi Tarihi: Sosyal, Ekonomik, Kültürel Temeller. İstanbul: Timaş Yayınları.

[10] Köy Enstitüleri ve Çağdaş Eğitim Vakfı. (2003). Köy Enstitüleri ve Çağdaş Eğitim Vakfı yayınları. Tanıtım dizisi: Vol. 14. Köy enstitüleri I-II. Ankara: Karatepe Yayınları.

[11] Makal, M. (2019). Bizim Köy. İstanbul: Literatür Yayınları.

[12] Oran, B. (1988). Atatürk Milliyetçiliği: Resmi Ideoloji Dışı Bir Inceleme. Dost Kitabevi.

[13] Özçukur, A. (1985). Köy Enstitüleri Destanı (Vol. 2). Ankara: Öğretmen yayınları.

[14] Şen, M. E., \& Türkmenoğlu, M. A. (2012). Avrupa Feodalitesi ile Osmanlı Tımar Sistemi Üzerine Bir Mukayese. The Journal of Academic Social Science Studies, 5(4), 189-204.

[15] Şimşek, A. (Ed.). (2019). Tarih için metodoloji: Söylem Analizi. Ankara: Pegem Akademi.

[16] Tonguç, İ. H. (Ed.). (1976). Mektuplarla köy enstitüsü yılları. İstanbul: Çağdaş Yayınları.

[17] Tonguç, I.H. (1934). Ilk tahsil kanunu. Ismail Hakkı Tonguc Archives Foundation (B01-21-2, p. 1-13), Ankara, Turkey.

[18] Tonguç, I.H. (ca. 1936). Köy öğretmen ve eğitmeni yetiştirme işi. İsmail Hakkı Tonguç Archives Foundation (P01-37-8B, p. 1-7), Ankara, Turkey.

[19] Tonguç, I.H. (ca.1941a). Köy Enstitüleri tesisi ve bu Enstitüleri bitirenlerin çalıştırılmaları hakkında. İsmail Hakkı Tonguç Archives Foundation (D01-105-23A, p. 1-14), Ankara, Turkey.

[20] Tonguç, I.H. (ca.1941b). Mustafa Gurbetçi'nin Enstitüye Gelişim isimli yazısı. İsmail Hakkı Tonguc Archives Foundation (D03-82-3C, p. 1-2), Ankara, Turkey.

[21] Tonguç, İ.H. (1941, December 22). İsmail Sönmez'in Enstitüye nasıl geldim isimli yazısı. İsmail Hakkı Tonguç Archives Foundation (D03-823D, p. 1-34), Ankara, Turkey.

[22] Tonguç, İ. H. (2008). Köyde eğitim (3rd ed.). Köy Enstitüleri ve Çağdaş Eğitim Vakfı yayınları. Tanıtım dizisi: Vol. 3. Köy Enstitüleri ve Çağdaş Eğitim Vakfı Yayınları.

[23] Tonguç, İ. H. (2020). Canlandırılacak köy. İstanbul: Türkiye İş Bankası Kültür Yayınları.

[24] Türk Dil Kurumu. (n.d.). Meclis. In Türk Dil Kurumu Sözlükleri. Retrieved February 2, 2021, from https://sozluk.gov.tr/

[25] Türkoğlu, P. (2019). Tonguç ve Enstitüleri. İstanbul: Türkiye İş Bankası Kültür Yayınları. Yıldız, N., \& Akandere, O. (2017). Köy Enstitülerinin İdeolojik Yapısı. Çağdaş Türkiye Tarihi Araştırmaları Dergisi, 17(35), $275-316$. 